\title{
Rhizosphere fungal community, soil physicochemical properties, understorey vegetation and their relationship during post-coal mining reclamation in East Kalimantan, Indonesia
}

\author{
SUDRAJAT ${ }^{1, \boldsymbol{}}$, BAYU WIDHAYASA $^{2}$, RUSDIANSYAH $^{3}$, DWI SUSANTO ${ }^{4}$ \\ ${ }^{1}$ Laboratorium Ecology, Faculty of Mathematics and Natural Sciences, Universitas Mulawarman. Jl. Barong Tongkok, Gunung Kelua, Samarinda 75123, \\ East Kalimantan, Indonesia. Tel.: +62-0541-749140, `email: sudrajat.fmipa @gmail.com. \\ ${ }^{2}$ Department of Environmental Sciences, Universitas Mulawarman. Gunung Kelua, Samarinda 75123, East Kalimantan, Indonesia \\ ${ }^{3}$ Faculty of Agriculture, Universitas Mulawarman. Jl. Pasir Belengkong, Gunung Kelua, Samarinda 75123, East Kalimantan, Indonesia \\ ${ }^{4}$ Laboratorium Plant Physiology, Faculty of Mathematics and Natural Sciences, Universitas Mulawarman. Gunung Kelua, Samarinda 75123, \\ East Kalimantan, Indonesia
}

Manuscript received: 17 May 2019. Revision accepted: 26 June 2019.

\begin{abstract}
Sudrajat, Widhayasa B, Rusdiansyah, Susanto D. 2019. Rhizosphere fungal community, soil physicochemical properties, understorey vegetation and their relationship during post-coal mining reclamation in East Kalimantan, Indonesia. Biodiversitas 20: 1953-1962. The objective of this study was to evaluate the composition of fungal community in rhizosphere, understorey vegetation and soil physicochemical properties post-coal mining reclamation. Soil sampling was conducted using a series of reclamation stages plots (undisturbed, disturbed, two, nine, twelves and sixteen years of reclamation) with drill ground at a depth of 0-30 cm. On each plot, fivepoint drilling was conducted; soil samples were composited; and their physicochemical properties including soil $\mathrm{pH}$, organic carbon, total $\mathrm{N}$, available $\mathrm{P}$, available $\mathrm{K}, \mathrm{Ca}, \mathrm{Mg}, \mathrm{Fe}, \mathrm{Mn}$, and $\mathrm{S}$ content were analyzed. Rhizosphere microfungi were isolated by using serial dilution and plated on potato dextrose agar added with Streptomycin. Identification and characterization of soil microfungi were done with the help of accessible manuals of fungi. The results showed that fungal genera at rhizosphere during post-coal mining reclamation were Aspergillus, Penicillium, Cephalosporium, Gliocladium, Humicola, Trichoderma, and Paecilomyces. Aspergillus was dominant comprising $74 \%$ of the total isolates. The fungal density in the undisturbed soil and the post-coal mining reclamation soil were higher than in the disturbed soil. The fungal rhizosphere groups isolated were saprophytic fungi that were present in a high relative density. In addition, the results showed that fungal rhizosphere was negatively correlated with soil $\mathrm{pH}$ and organic carbon. On the other hand, fungal rhizosphere was positively correlated with total N, available $\mathrm{P}$, and available $\mathrm{K}$. It can be concluded that the time period of postcoal mining reclamation, vegetation, and soil physicochemical profoundly determined the soil fungal community.
\end{abstract}

Keywords: Microfungal rhizosphere, post-coal mining reclamation, soil physicochemical

\section{INTRODUCTION}

The activities at coal mining sites cause drastic disturbances in a landscape and alter the ecological environment, thereby disrupting the functional stability of the soil microbial community. This condition needs to be rehabilitated by conducting reclamation and revegetation. The ultimate goal of mine land reclamation and revegetation is the reestablishment of a productive, healthy, and sustainable ecosystem that is suitable for land use. Currently, only aboveground indicators such as soil erosion and vegetation characteristics such as production, cover, diversity, and shrub density are considered in determining reclamation success.

The long-term goal of reclamation and revegetation is to improve the condition of the microclimate, biodiversity, wildlife habitats, and the condition of the land to be more protected, conserved and productive (Mummey et al. 2002; Rana et al. 2007; Yusuf and Arisoesilaningsih 2017). The most important aspect in ecosystem recovery is soil characteristic. Soil quality serves so many important ecosystems for not only human beings but also the other organism in an environment (Noviyanto et al. 2017). The microbial community in soil is fundamental for organic matter transformation and plays a principal role in the biogeochemical cycles in this ecosystem. Soil microbes are vital for the continuous cycling of nutrient and for driving aboveground ecosystems. Considering its importance, restoration of soil structure and function is essential for restoration success in post-mining areas. Previous studies have shown that soil microbial community succession of bacterial, archaeal and, fungal communities were assessed by tag encoded 454 pyrosequencing. At the phylum level, Proteobacteria, Crenarchaeota, and Ascomycota had the highest detected relative abundance within bacteria, archaea, and fungi, respectively (Li et al. 2016).

Soil health, and the closely related terms of soil quality and fertility, is considered one of the most important characteristics of soil ecosystems. The integrated approach to soil health assumes that soil is a living system and soil health results from the interaction between different processes and properties, with a strong effect on the activity of soil microbiota. All soils can be described using physical, chemical, and biological properties, but adaptation to environmental changes, driven by the processes of natural selection, are unique to the latter one 
(Frac et al. 2018).

Management practices significant impact on the composition of the soil microbes, and changes in the microbial community composition or activity could have immediate or long-term effects on the functioning of the ecosystem (Gomez et al. 2016). Changes in the microbial community can precede detectable changes in soil physic and chemical properties, thereby providing early signs of environmental stress or ecological environment evolution in the post-coal mining sites ( $\mathrm{Li}$ et al. 2014). The presence of soil microbes can increase the ability to return to the natural conditions of a degraded land ecosystem due to coal mining activities (Birch et al. 1991). It is important to study microbial diversity not only for basic scientific research but also to understand the link between diversity and community structure and function (Meliani et al. 2012). Fungal rhizosphere regulates important roles in ecosystem processes, however, the response of soil fungal communities to post-coal mining reclamation has not been well understood. The objective of this study was to determine the microfungal rhizosphere and soil chemical properties in a post-coal mining reclamation soil during the initial stage of plant community development.

\section{MATERIALS AND METHODS}

\section{Study area}

The materials used in this study were soils from the Embalut Coal Mining Site in Embalut Village, Tenggarong Seberang Sub-District, Kutai Kartanegara District, East Kalimantan Province, Indonesia (Figure 1). Soil samples were collected from five reclaimed areas and no disturbance as the control. The minimum and maximum daily temperatures were $27^{\circ}$ to $35^{\circ} \mathrm{C}$, the mean monthly humidity was $91 \%$ and the mean monthly precipitation was $176.2 \mathrm{~mm}$. Laboratory analysis was conducted in the Soil Science Laboratory of Tropical Rain Forest Research Center and Plant Protection Laboratory, Faculty of Agriculture, Mulawarman University. A sampling method was used to take the samples in a research location which represented the condition of every location. The reclaimed coal mining site varied in age, soil characteristics, vegetation, and type of post-mining revegetation treatment (Figure 2). A summary of each reclaimed coal mining sites is presented in Table 1.

\section{Procedures}

The samples of soil are through six different stages of reclamation, namely: undisturbed, two years after reclamation, nine-years after reclamation, twelve years after reclamation and sixteen years after reclamation (Table 1). For each stage of reclamation, three plots of $10 \mathrm{~m} \mathrm{x} 10$ $\mathrm{m}$ were made. Once coordinate points were determined using GPS, numbers of fungal propagules and soil physicochemical properties were measured.

\section{Soil sampling}

Rhizosphere soil samples were collected from the plots with ground drilling at a depth of $0-30 \mathrm{~cm}$. On each plot, five-point drilling was determined and soil samples were composited. $500 \mathrm{~g}$ composite soil samples were taken from each class of depth, put into plastic bags, labeled and transported to the laboratory. Fungal propagules were determined from fresh soil samples. Soil physicochemical properties were determined from air-dried soil samples.

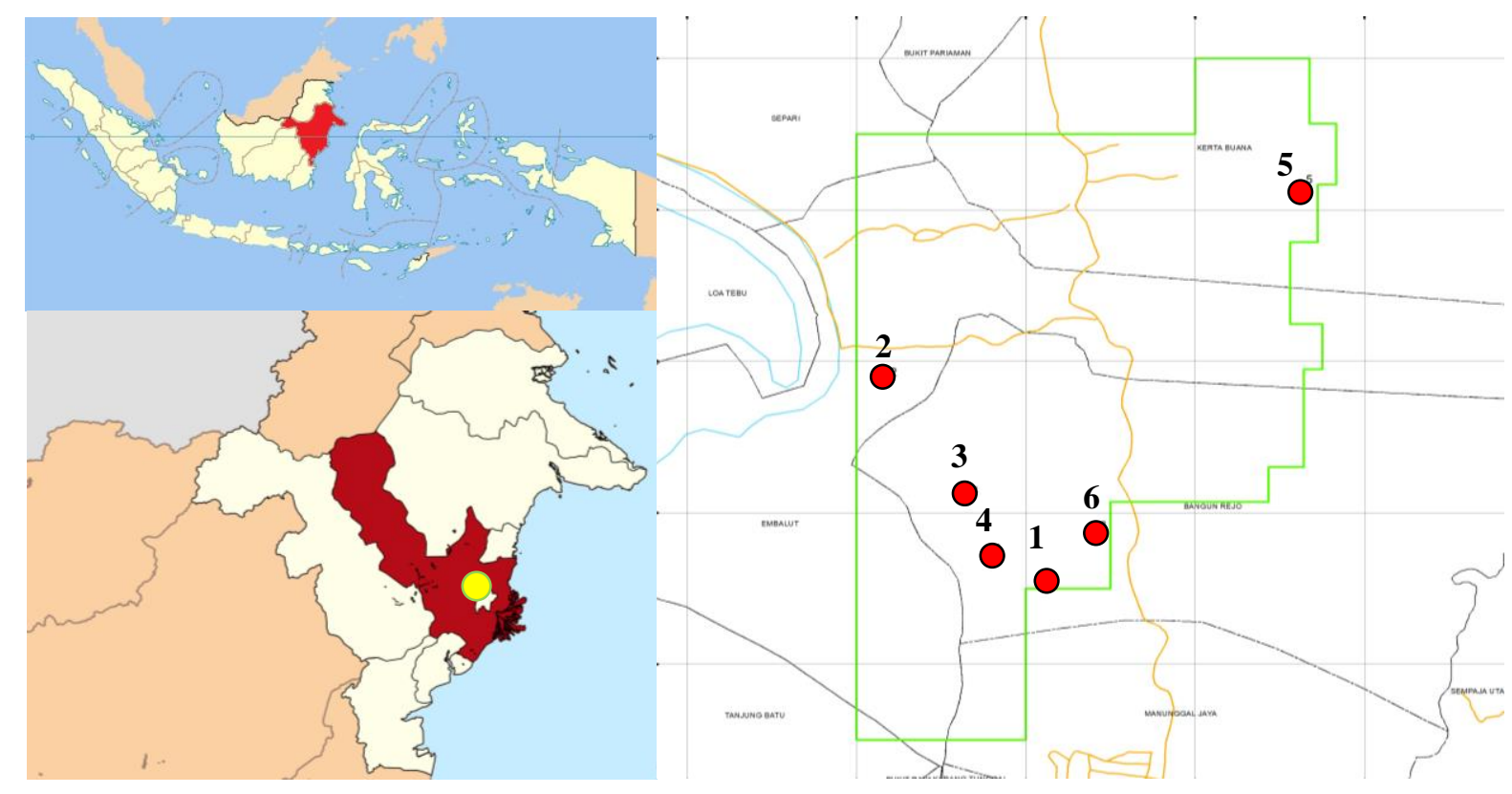

Figure 1. Location of the Study area in Embalut Village, Tenggarong Seberang Sub-District, Kutai Kartanegara District, East Kalimantan Province, Indonesia (red circles are reclamation areas). 1. Undisturbed area, 2. Disturbed area, 3. Two years after reclamation, 4. Nine years after reclamation, 5. 12 years after reclamation; 6.16 years after reclamation. 
Table 1. Description of the study sites in the Embalut Coal Mining Site, Kutai Kartanegara District, East Kalimantan, Indonesia

\begin{tabular}{|c|c|c|}
\hline Plot (age in years) & Coordinate & Vegetation \\
\hline \multirow[t]{2}{*}{ Undisturbed } & S 021'29.4444"' & Stenotaphrum secundatum, Ageratum conyzoides, \\
\hline & E $117^{\circ} 6 ’ 7.2864^{\prime \prime}$ & Asystasia gangetica, Chromolaena odorata \\
\hline \multirow[t]{2}{*}{ Disturbed } & S 0'20’8.484” & Paspalum conjugatum, Cynodon dactylon, \\
\hline & E $117^{\circ} 5^{\prime} 10.3632^{\prime \prime}$ & Cyperus odoratus, Eclipta prostate, Chromolaena odorata \\
\hline Two years after reclamation & $\begin{array}{l}\text { S } 0^{\circ} 20^{\prime} 55.5144^{\prime \prime} \\
\text { E } 117^{\circ} 5^{\prime} 39.0624^{\prime \prime}\end{array}$ & $\begin{array}{l}\text { Senna siamea, Duabanga moluccana, Terminalia catappa, Morinda } \\
\text { citrifolia, Samanea saman }\end{array}$ \\
\hline Nine years after reclamation & $\begin{array}{l}\text { S } 0^{\circ} 21^{\prime} 18.288^{\prime \prime} \\
\text { E } 117^{\circ} 5^{\prime} 47.1696^{\prime \prime}\end{array}$ & $\begin{array}{l}\text { Senna siamea, Samanea saman, Enterolobium cyclocarpum, Hibiscus } \\
\text { tiliaceus, Gliricidia sepium }\end{array}$ \\
\hline Twelve years after reclamation & $\begin{array}{l}\text { S } 0^{\circ} 18^{\prime} 52.092^{\prime \prime} \\
\text { E } 117^{\circ} 7^{\prime} 37.4664^{\prime \prime}\end{array}$ & $\begin{array}{l}\text { Enterolobium cyclocarpum, Samanea saman, } \\
\text { Acacia mangium, Gmelina arborea }\end{array}$ \\
\hline Sixteen years after reclamation & $\begin{array}{l}\text { S } 0^{\circ} 21^{\prime} 9.5436^{\prime \prime} \\
\text { E } 117^{\circ} 6^{\prime} 33.7608^{\prime \prime}\end{array}$ & Senna siamea, Enterolobium cyclocarpum, Gliricidia sepium \\
\hline
\end{tabular}

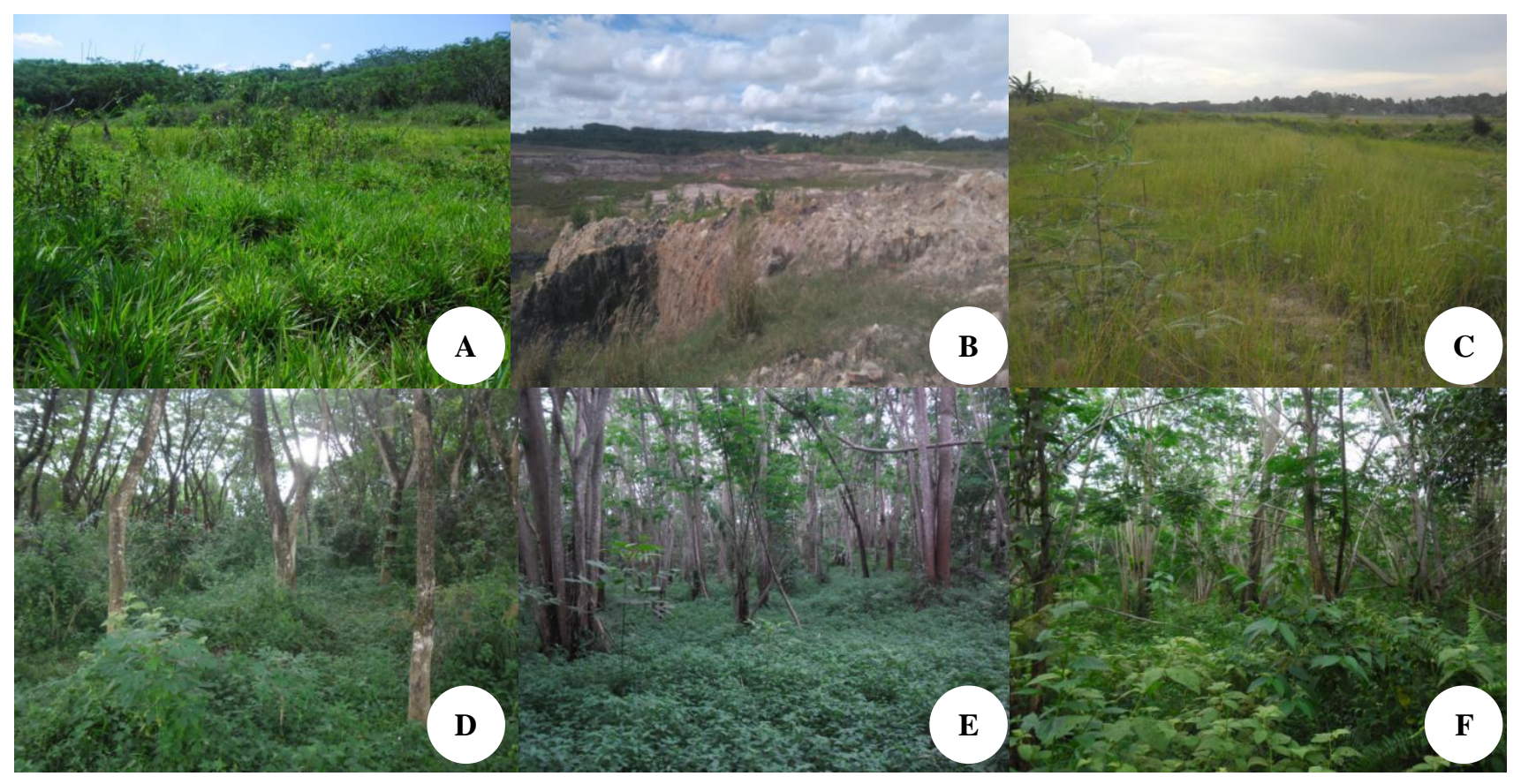

Figure 2. Illustration of sampling areas in the Embalut Coal Mining Site, Kutai Kartanegara District, East Kalimantan Province, Indonesia. A. Undisturbed area; B. Disturbed area; C. Two years after reclamation; D. Nine years after reclamation; E. 12 years after reclamation; F. 16 years after reclamation

\section{Fungal rhizosphere counting}

Fungal rhizosphere propagules were estimated using serial dilution method and plated on potato dextrose agar. Soil samples $(1 \mathrm{~g})$ were added to $10 \mathrm{ml}$ sterilized distilled water and shaken for $15 \mathrm{~min}$. The original suspension (1 $\mathrm{ml}$ ) was diluted in $9 \mathrm{ml}$ of sterilized distilled water. Series of soil dilutions of 1:10,1:100,1:1,000 were prepared.Each soil suspension was spread in triplicate series. Plates were incubated at $240^{\circ} \mathrm{C}$ under light/dark cycles for 3-4 days before measurement. Data from triplicate readings were expressed as colony forming unit (CFU) $\mathrm{g}^{-1}$ of dry soil. After the measurement, isolates of the original specimens were transferred to potato dextrose agar with chloramphenicol (300 $\left.\mathrm{mg} \mathrm{l}^{-1}\right)$ slant tubes. The fungal isolates were identified to the genus level and in some cases, species level, using standard keys based on morphological features (Barnett and Hunter 1972; Domsch et al. 1980). Percentage of the relative abundance of the fungal species was calculated using the following formula:

$$
\% \text { of relative abundance }=\quad \frac{\begin{array}{c}
\text { Total number of colonies of a } \\
\text { particular genus/species }
\end{array}}{\begin{array}{c}
\text { Total number of colonies of } \\
\text { all the genera } / \text { species }
\end{array}} \times 100
$$

Soil analysis

The soil sample was taken from the depth of 0-30 cm and the results were calculated after being dried in the oven with the temperature of $150^{\circ} \mathrm{C}$ until constant weight was reached. Three major soil nutrient components and other two soil properties, namely soil $\mathrm{pH}$, organic carbon, total 
nitrogen, available phosphorus, and available potassium, were measured. The $\mathrm{pH}$ was determined using a $\mathrm{pH}$ meter (water-to-soil ratio $1: 2.5$ ); soil organic carbon was determined by the Walkley-Black method; total $\mathrm{N}$ was determined by Kjeldahl determination; available $\mathrm{P}$ was determined using Spectronic method; and available K was determined using Atomic Absorption Spectrophotometry.

\section{Data analysis}

Variations in fungal rhizosphere propagules and the soil physicochemical properties were analyzed using standard analysis of variance. Statistical analysis was undertaken using SPSS statistical software version 21.0. All data were expressed as the mean \pm standard deviation. The Least Significant Difference (LSD) test was used to compare fungal propagules and soil physicochemical properties mean at the $5 \%$ probability level.

\section{RESULTS AND DISCUSSION}

\section{Soil characteristics}

Table 1 shows that there was a significant variation $(\mathrm{p}<0.05)$ in the chemical properties among the reclamation stages of different age groups. The $\mathrm{pH}$ values of samples ranged from 6.27 to 8.47 indicating that they were neutral and moderately alkaline. The concentrations of organic carbon status were medium $(2.57$ to $2.81 \%)$ to high (3.69 to $3.75 \%)$. Organic carbon concentrations in the 9 and 12 years after reclamation were significantly higher than the undisturbed soil and the older reclamation soil. The concentration of organic carbon increased in 2 years after reclamation and then decreased after 9 years after reclamation. Total $\mathrm{N}$ ranged from 0.08 to $0.18 \%$ including low and very low categories. This study shows that two years after reclamation soil had significantly lower total $\mathrm{N}$ concentration than the undisturbed soil of the reclaimed sites. The concentration of available $\mathrm{P}$ has the status of extremely low (1.69 to $4.18 \mathrm{ppm}$ ) to medium (6.37 to 8.26 $\mathrm{ppm})$. The available $\mathrm{P}$ concentrations in the nine years after reclamation soil were significantly higher than the disturbed soil and the youngest reclamation soil. The concentration of available $\mathrm{K}$ status was low (74.04 to
$155.69 \mathrm{ppm})$. Considering all the reclamation stages, the twelve years after reclamation stage exhibited significantly lower available $\mathrm{K}$ concentration indices than other reclamation stages. The concentration of total $\mathrm{N}$, available $\mathrm{P}$ and available $\mathrm{K}$ generally increased in the early years after reclamation but decreased slightly in more than ten years after reclamation. The contents of $\mathrm{Ca}, \mathrm{Mg}, \mathrm{Fe}, \mathrm{Mn}$ and $\mathrm{S}$ for disturbed area was higher than the undisturbed area indicating that coal mining and soil process reclaimed may affect the metal exposed from the soil.

\section{Composition and diversity of understorey vegetation}

The results of the observation show that, among the study sites, there were differences total plant species and in importance value of index species composition and familial families in the land stands after coal mining reclamation (Fig 3 and Table 2). From Table 2, the amount of IVI is known and there is a predominance of three understorey species in the study sites, namely Paspalum conjugatum, Asystasia gangetica, and Stenotaphrum secundatum. Paspalum conjugatum was dominant in active mining sites in 2 and 16 years after coal mining reclamation. Asystasia gangetica was dominant inland in 9 and 12 years after coal mining reclamation. While the type of understorey in nonmining land was dominated by the Stenotaphrum secundatum. The dominance of the three species of understorey was because they belong to a group of clumps that are able to breed in large quantities and quickly dominate a land community compared to other plant species.

The results of the Shannon-Wiener $\left(\mathrm{H}^{\prime}\right)$ diversity index analysis from each study site can be seen in Figure 4. Land that has been reclaimed showed a relatively higher diversity index value compared to non-mining land and active mining. The results of the Pielou (e) evenness index analysis formed a pattern similar to the Shannon-Wiener $(\mathrm{H}$ ') diversity index that has been reclaimed shows a relatively higher Pielou evenness index compared to non-mining land and active mining. The Pielou (e) evenness index value in non-mining land is relatively low compared to other locations due to the dominance of certain species despite relatively high species and family wealth.

Table 1. Physicochemical properties of different reclaimed ages

\begin{tabular}{lrrrrrr}
\hline \multirow{2}{*}{ Parameter } & \multicolumn{5}{c}{ Plots (years after reclamation) } \\
\cline { 2 - 7 } & \multicolumn{1}{c}{ Undisturbed } & \multicolumn{1}{c}{ Disturbed } & \multicolumn{1}{c}{ 2 year } & \multicolumn{1}{c}{ year } & \multicolumn{1}{c}{ 12 year } & \multicolumn{1}{c}{ 16 year } \\
\hline pH & $6.27 \pm 1.78^{\mathrm{a}}$ & $7.85 \pm 0.1^{\mathrm{bc}}$ & $8.47 \pm 0.07^{\mathrm{c}}$ & $6.12 \pm 0.72^{\mathrm{a}}$ & $6.96 \pm 0.49^{\mathrm{abc}}$ & $6.82 \pm 0.20^{\mathrm{abc}}$ \\
SOM (\%) & $2.57 \pm 0.15^{\mathrm{a}}$ & $3.69 \pm 0.72^{\mathrm{b}}$ & $2.81 \pm 0.17^{\mathrm{a}}$ & $3.75 \pm 0.72^{\mathrm{b}}$ & $3.73 \pm 0.09^{\mathrm{b}}$ & $2.67 \pm 0.36^{\mathrm{a}}$ \\
Total N (\%) & $0.14 \pm 0.02^{\mathrm{b}}$ & $0.13 \pm 0.02^{\mathrm{ab}}$ & $0.08 \pm 0.03^{\mathrm{a}}$ & $0.18 \pm 0.05^{\mathrm{b}}$ & $0.17 \pm 0.04^{\mathrm{b}}$ & $0.13 \pm 0.02^{\mathrm{ab}}$ \\
Available P (ppm) & $3.49 \pm 0.71^{\mathrm{abc}}$ & $1.69 \pm 1.4^{\mathrm{a}}$ & $2.81 \pm 1.11^{\mathrm{a}}$ & $8.26 \pm 1.1^{\mathrm{d}}$ & $6.37 \pm 3.65^{\mathrm{cd}}$ & $4.18 \pm 0.71^{\mathrm{abc}}$ \\
Available K (ppm) & $127.55 \pm 18.78^{\mathrm{c}}$ & $147.33 \pm 8.21^{\mathrm{d}}$ & $149.35 \pm 2.51^{\mathrm{d}}$ & $155.69 \pm 2.0^{\mathrm{d}}$ & $74.04 \pm 2.31^{\mathrm{a}}$ & $92.02 \pm 0.96^{\mathrm{b}}$ \\
Ca (meq.100 g-1) & $1.53 \pm 0.91^{\mathrm{a}}$ & $8.12 \pm 0.51^{\mathrm{d}}$ & $4.57 \pm 0.36^{\mathrm{c}}$ & $3.52 \pm 0.33^{\mathrm{b}}$ & $5.12 \pm 0.72^{\mathrm{c}}$ & $9.16 \pm 0.43^{\mathrm{e}}$ \\
Mg (meq.100 g-1) & $1.83 \pm 1.32^{\mathrm{a}}$ & $6.28 \pm 0.29^{\mathrm{c}}$ & $4.43 \pm 0.32^{\mathrm{b}}$ & $4.73 \pm 0.46^{\mathrm{b}}$ & $6.14 \pm 0.77^{\mathrm{c}}$ & $8.55 \pm 0.19^{\mathrm{d}}$ \\
Fe (mg.kg & $2,404.04 \pm 47.57^{\mathrm{a}}$ & $2,380.95 \pm 21.7^{\mathrm{a}}$ & $2,315.04 \pm 17.10^{\mathrm{a}}$ & $2,280.11 \pm 17.42^{\mathrm{a}}$ & $2,356.72 \pm 23.74^{\mathrm{a}}$ & $2,380.38 \pm 23.92^{\mathrm{a}}$ \\
Mn(mg.kg-1) & $312.31 \pm 123.45 \mathrm{ab}$ & $754.78 \pm 20.10 \mathrm{~d}$ & $474.51 \pm 15.54 \mathrm{bc}$ & $175.81 \pm 77.05 \mathrm{a}$ & $494.55 \pm 192.69 \mathrm{bc}$ & $666.40 \pm 90.38 \mathrm{~cd}$ \\
$\mathrm{~S}(\%)$ & $4.91 \pm 0.01 \mathrm{a}$ & $39.76 \pm 15.89 \mathrm{c}$ & $13.39 \pm 4.10 \mathrm{ab}$ & $29.15 \pm 13.49 \mathrm{bc}$ & $27.63 \pm 13.39 \mathrm{bc}$ & $13.09 \pm 0.019 \mathrm{ab}$ \\
\hline
\end{tabular}

Note: $\mathrm{n}=3$, mean SE) of soil for each site. Values followed by different letters (a, b, c, d, e) between location are significantly different $(\mathrm{P}<0.05)$ according to Duncan's multiple comparison. SOM, Soil organic matter; Total N, Total nitrogen; Available P; Available K, Available potassium 
Table 2. The results of importance value index of understorey vegetation on land post-coal mining reclamation

\begin{tabular}{|c|c|c|c|c|c|c|c|}
\hline \multirow{2}{*}{ Species } & Family & Undisturbed & Disturbed & 2 year & 9 year & 12 year & 16 year \\
\hline & \multicolumn{7}{|c|}{ Importance Value Index (IVI) } \\
\hline Ageratum conyzoides & Asteraceae & 13.71 & & & 7.7 & 20.27 & 6.74 \\
\hline Chromolaena odorata & Asteraceae & 12.20 & 11.5 & & & & \\
\hline Mikania micrantha & Asteraceae & 5.38 & & & 6.63 & & \\
\hline Eclipta prostate & Asteraceae & 24.88 & & & & & \\
\hline Chromolaena odorata & Asteraceae & & & 13.84 & & & \\
\hline Eupatorium odoratum & Asteraceae & & & & & & 11.51 \\
\hline Melastoma malabatrichum & Melastomaceae & 11.14 & & & 6.0 & & \\
\hline Paspalum distichum & Poaceae & 5.71 & 122.71 & 65.34 & & & 84.54 \\
\hline Pennisetum purpureum & Poaceae & 5.43 & & & 87.10 & & \\
\hline Isachne globosa & Poaceae & 5.43 & & & & & \\
\hline Stenotaphrum secundatum & Poaceae & 106.72 & & & & & \\
\hline Cynodon dactylon & Poaceae & 26.65 & & & & & \\
\hline Paspalum distichum & Poaceae & & & & & 11.60 & \\
\hline Ischaemum timorense & Poaceae & & & 23.37 & & 19.4 & \\
\hline Digitaria sanguinalis & Poaceae & & & & 26.8 & & \\
\hline Fimbristylis miliacea & Cyperaceae & 5.49 & & & & & \\
\hline Cyperus odoratus & Cyperaceae & & 14.21 & 11.46 & & & \\
\hline Cyperus rotundus & Cyperaceae & & & & 6.63 & & \\
\hline Asystasia gangetica & Acanthaceae & 17.47 & & & & 79.68 & 25.33 \\
\hline Calopogonium mисunoides & Fabaceae & 5.88 & & & & & 5.05 \\
\hline Pueraria javanica & Fabaceae & & & 60.58 & & & 7.31 \\
\hline Mimosa pudica & Fabaceae & & & 13.84 & & & \\
\hline Solanum torvum & Solanaceae & & & 11.46 & 21.5 & & 11.22 \\
\hline Capsicum frutescens & Solanaceae & & & & 6.0 & & \\
\hline Nephrolepis falcate & Nephrolepidaceae & & & & 6.09 & 32.96 & 10.94 \\
\hline Matteuccia struthiopteris & Onolaceae & & & & 10.93 & & \\
\hline Piper aduncum & Piperaceae & & & & & 16.37 & 5.33 \\
\hline Taenitis blechnoides & Pteridaceae & & & & & 11.60 & 5.90 \\
\hline Urena lobata & Malvaceae & & & & & & 5.05 \\
\hline Passiflora foetida & Passifloraceae & & & & & & 7.31 \\
\hline Baccaurea polyneura & Phyllanthaceae & & & & & 8.19 & \\
\hline Phyllanthus niruri & Phyllanthaceae & & & & & & 6.74 \\
\hline Cyclosorus interruptus & Thelypteridaceae & & & & & & 7.03 \\
\hline
\end{tabular}

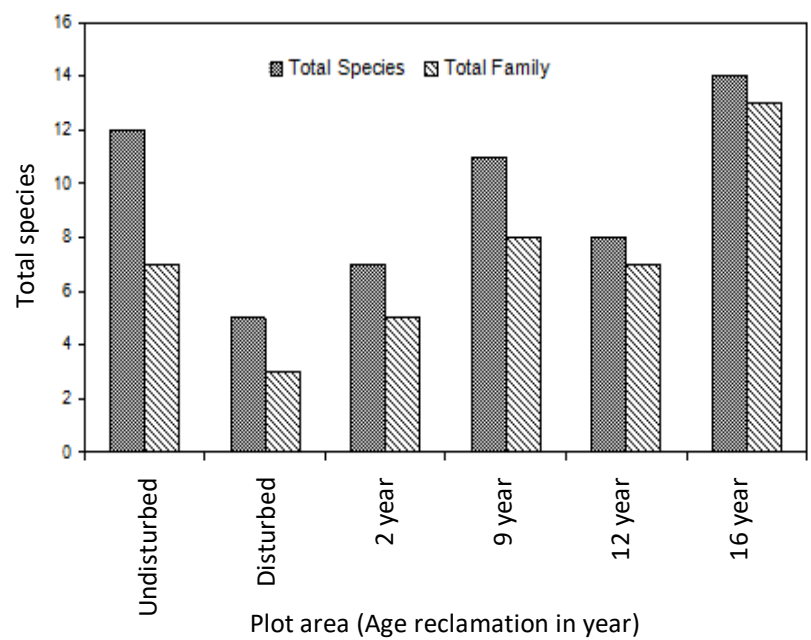

Figure 3. Total plant species at different age post-coal mining reclamation sites

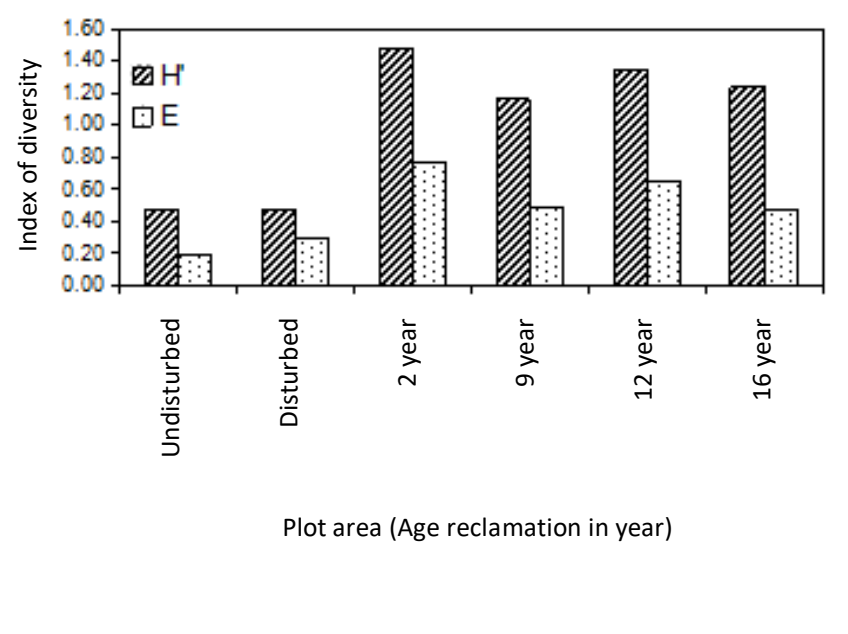

Figure 4. Shanon-Wiener Diversity index (H') and Pielou evenness index (E) of understorey vegetation on Post-reclamation Area 


\section{Fungal rhizosphere communities}

Numbers of fungal propagules were significantly different in the undisturbed soil, the disturbed soil or the reclaimed soil $(\mathrm{P}<0.05)$ (Table 3$)$. Numbers of fungal propagules in the undisturbed soil differ with the post-coal mining reclamation. Fungal propagules show increased in the year after reclamation but not significant and then decreased after twelve years of reclamation compared to undisturbed soil. This result indicates that fungal rhizosphere propagules were different in soils under different vegetation covers. The decline in fungal propagules probably reflected the exhaustion of added carbon and nitrogen from the litter. Each site had a different fungal propagule, thus indicating that a given fungal group had a close relationship to a specific plant successional stage of vegetation.

Distribution number of fungal genera in the various stages of reclamation can be seen in Table 4 . The result shows that many fungal genera isolated from the reclamation of coal mining sites were common to all areas. In this study, the important fungal genera with respect to the number of propagules isolated were Aspergillus, Penicillium, Cephalosporium, Gliocladium, Humicola, Trichoderma, and Paecilomyces (Figure 5). They were among the fungi found colonizing in the soil and the most diverse and ecologically significant group of fungi on the rhizosphere. However, some appeared in considerably higher densities than others. Aspergillus was the dominant genus that comprised $74 \%$ of the total isolates from these reclamation areas. After nine years of reclamation, the soil had higher fungal propagules but lower fungal diversities than disturbed soil.

\section{Relationship between plant diversity and abundance of soil fungi}

The results of correlation test show that the ShannonWiener diversity index $\left(\mathrm{H}^{\prime}\right)$ and Pielou (E) evenness of plants have a weak positive correlation with the abundance of soil fungi (Figure 6 and Figure 7). A low correlation coefficient is caused by very diverse environmental conditions. Thus, the abundance of soil fungi on post-coal mining reclamation soil is not only related to plant diversity but also related to environmental conditions.

The results of this study have not been able to show the factors related to the abundance of soil fungal populations, especially their association with the existence of plants on post-coal mining reclamation; however, plant analysis and soil sampling have been carried out specifically on the same plot. The existence of plants in the location of observation is suspected to be less diverse. Therefore, further research with a higher level of diversity of plants is still needed to identify the plant diversity with abundance of land after coal mining reclamation. This is because plants have a role as a bridge between the ecosystem above and in the soil. Turnbull et al. (2016) stated that ecosystems function better when they contain more species. GarciaPalacious et al. (2015) state that changes in plant structure will affect soil conditions, including processes of soil formation, soil structure and microbial community of soil, in this case, the abundance of soil fungi. This is supported by Widyati (2013) who stated that plants influence the soil microbial community through the provision of $\mathrm{C}$ through root exudates. As a result, the activity and number of microorganisms around the roots (rhizosphere) will be far greater than the surrounding soil. Different plants will produce different types and compositions of exudates that will determine the composition of the diversity of soil microbial communities.

\section{Discussion}

The results presented in Figure 2 show that the fungal rhizosphere propagules in the undisturbed soil and the postcoal mining reclamation soil were higher compared to the disturbed soil. The changes in the ecosystem structure have an impact on the composition of the fungal propagules in the reclamation areas. Our interpretation is that the dynamics of the fungal propagules observed seem to be related to changes in the availability of carbon resources occurring during degradation, and that the low numbers of fungal propagules could have been due to the absence of organic matter in the form of litter (Frezquez et al. 1987; Gomez et al. 2016)

Table 3. Density of fungal rhizosphere propagules $\sum$ colony $\left(\mathrm{CFU} . \mathrm{g}^{-1}\right) * 10^{3}$ in various stages of reclamation

\begin{tabular}{|c|c|c|c|c|}
\hline \multirow{2}{*}{$\begin{array}{l}\text { Years after } \\
\text { reclamation }\end{array}$} & \multicolumn{3}{|c|}{ 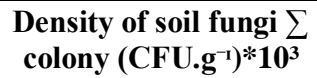 } & \multirow[t]{2}{*}{ Mean } \\
\hline & $\mathbf{I}$ & II & III & \\
\hline Undisturbed & 130 & 75 & 105 & $103.33 \pm 15.89^{\mathrm{ab}}$ \\
\hline Disturbed & 10 & 85 & 15 & $36.67 \pm 24.20^{\mathrm{a}}$ \\
\hline 2-year & 125 & 40 & 90 & $85.00 \pm 24.20^{\mathrm{ab}}$ \\
\hline 9-year & 110 & 170 & 80 & $120.00 \pm 26.45^{b}$ \\
\hline 12-year & 75 & 40 & 120 & $78.33 \pm 23.15^{\mathrm{ab}}$ \\
\hline 16-year & 130 & 84 & 45 & $86.33 \pm 24.56^{\mathrm{ab}}$ \\
\hline
\end{tabular}

Note: Values followed by different letters(a,b,c,d,e) between location are significantly different $(\mathrm{P}<0.05)$ according to Duncan's multiple comparisons

Table 4. Distribution number of fungal genera in the various stages of reclamation

\begin{tabular}{lcccccc}
\hline \multirow{2}{*}{ Fungal groups $\begin{array}{c}\text { Un- } \\
\text { disturbed }\end{array}$} & & \multicolumn{7}{c}{ Years after reclamation } \\
\cline { 4 - 7 } & & & $\begin{array}{c}\text { 2- } \\
\text { year }\end{array}$ & $\begin{array}{c}\text { 9- } \\
\text { year }\end{array}$ & $\begin{array}{c}\text { 12- } \\
\text { year }\end{array}$ & $\begin{array}{c}\text { 16- } \\
\text { year }\end{array}$ \\
\hline Aspergillus & 7 & 6 & 5 & 6 & 4 & 6 \\
Penicillium & 1 & 0 & 1 & 1 & 0 & 1 \\
Cephalosporium & 0 & 1 & 0 & 0 & 0 & 0 \\
Gliocladium & 0 & 1 & 0 & 0 & 1 & 0 \\
Humicola & 0 & 0 & 0 & 0 & 1 & 0 \\
Trichoderma & 0 & 0 & 0 & 0 & 1 & 0 \\
Paecilomyces & 0 & 0 & 1 & 0 & 0 & 0 \\
Unidentified & & & & & & \\
Isolate No. 1 & 1 & 0 & 0 & 0 & 0 & 0 \\
Isolate No. 2 & 0 & 0 & 0 & 0 & 1 & 0 \\
No. of isolates & 9 & 8 & 7 & 7 & 8 & 7 \\
No. of genera & 3 & 3 & 3 & 2 & 5 & 2 \\
\hline
\end{tabular}




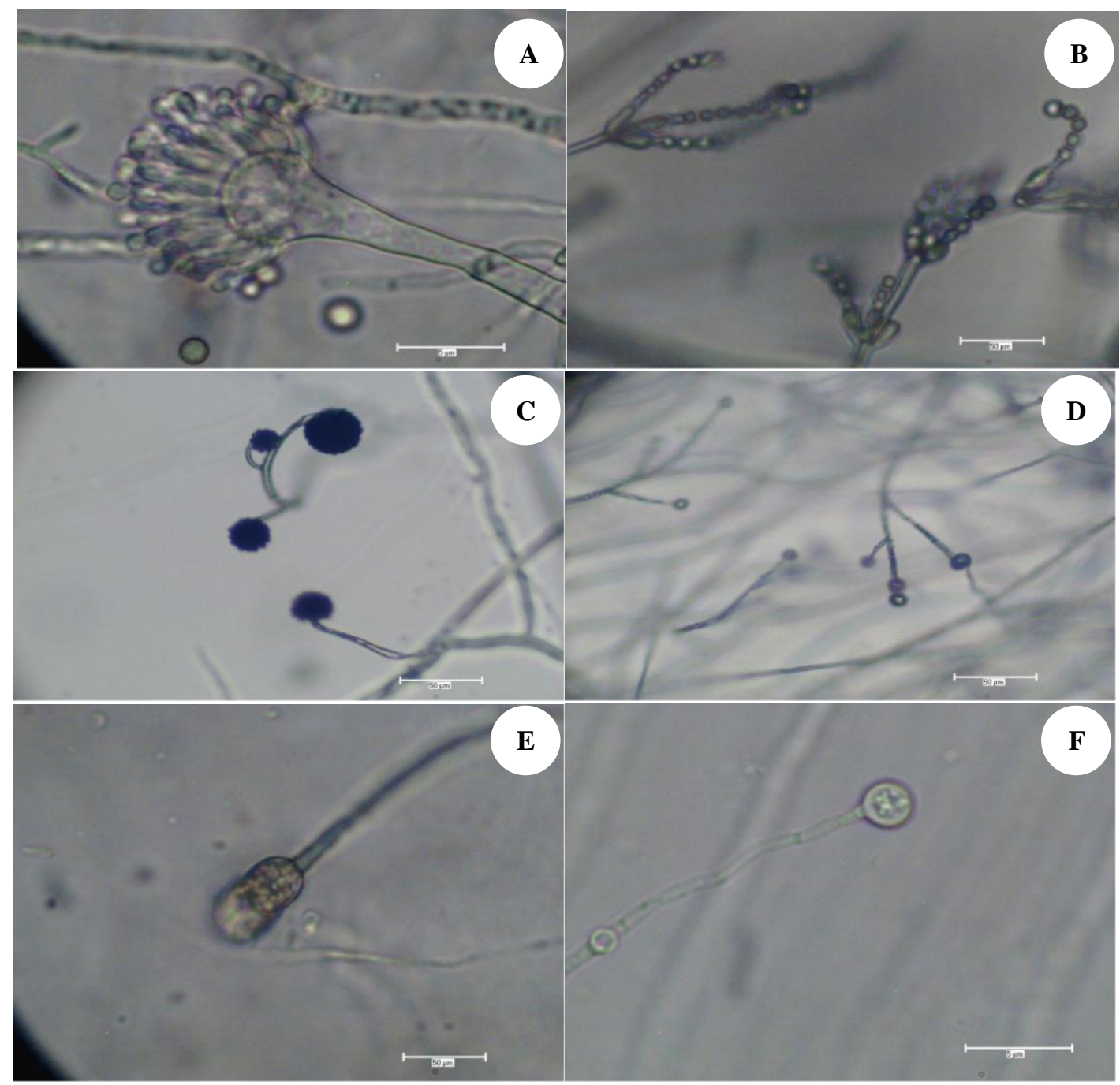

Figure 5. Several types of soil fungi identified from post-coal mining reclamation soil. A. Aspergillus sp.; B. Penicillium sp.; C. Gliocladium sp.; D. Trichoderma sp.; E. Not yet identified; F. Not yet identified

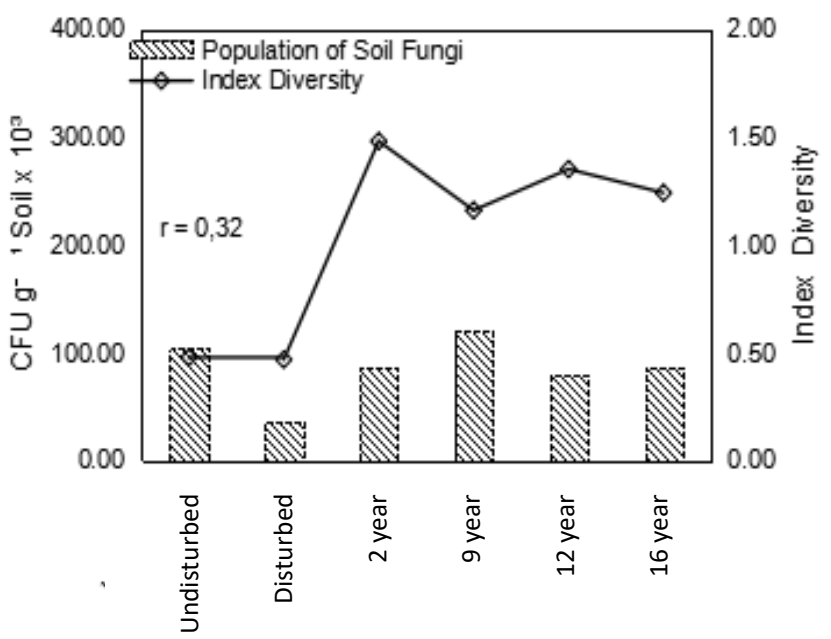

Figure 6. Relationship between index of plants diversity with abundance of soil fungi on post-reclamation

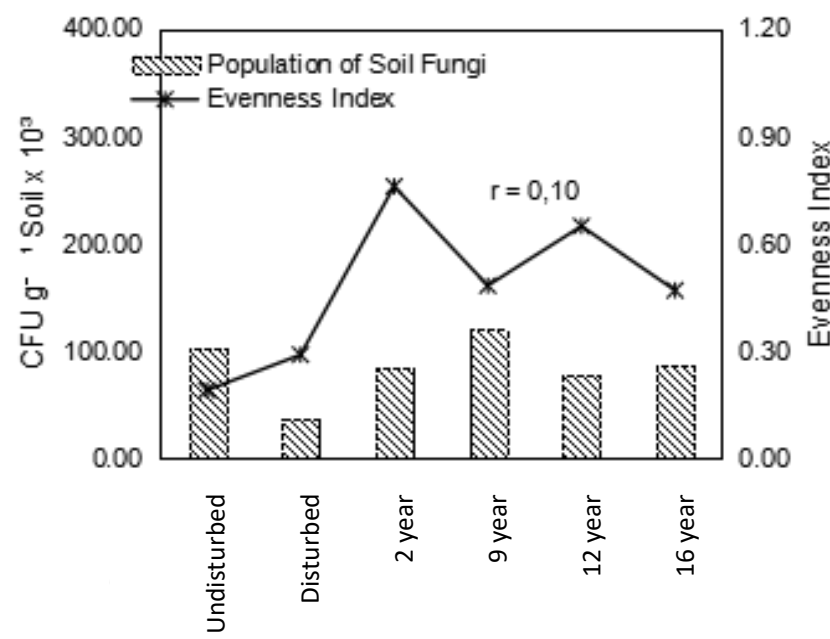

Figure 7. Relationship between index of plants diversity with abundance of soil fungi on post-coal mining reclamation 

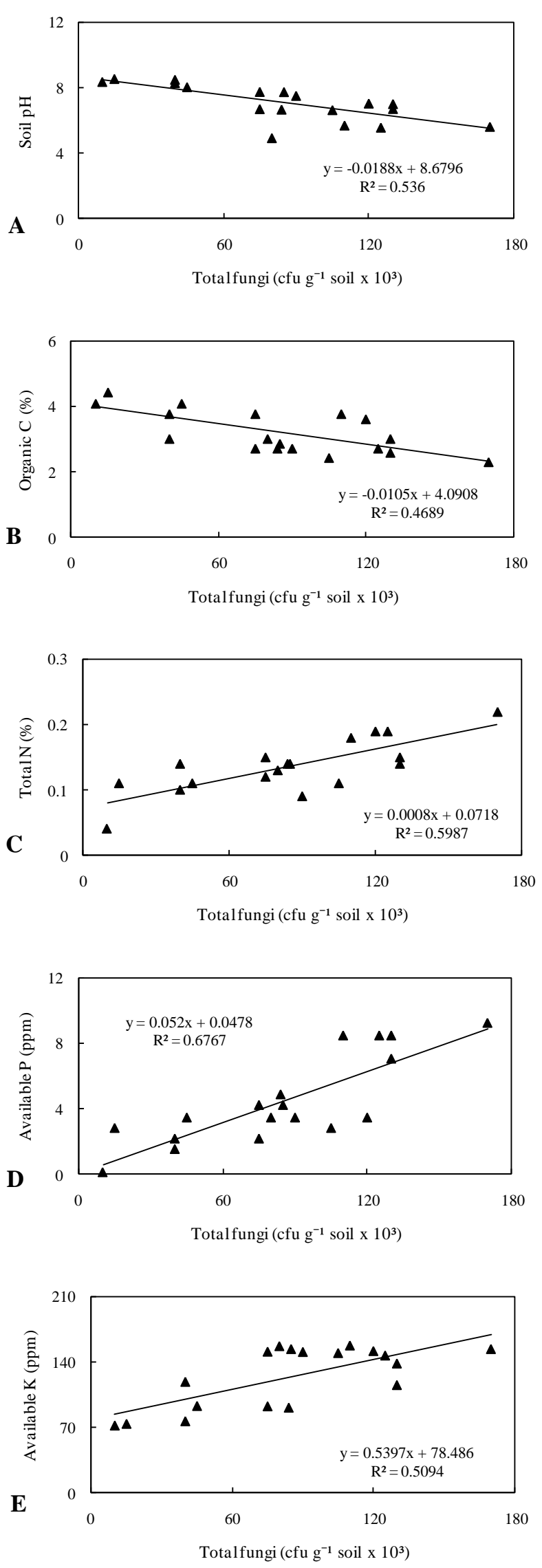

Figure 8. Relationship between fungal rhizosphere with: A. Soil $\mathrm{pH}$, B. Organic carbon, C. Total N, D. Available P, E. Available $\mathrm{K}$ at reclamation areas
We also expected that changes in fungal propagules would be strongly linked to vegetation dynamics. Our results show that the numbers of fungi propagules differed appreciably from one ecological area to the others which were influenced by vegetation cover and especially by soil factors. Our data indicate that fungal rhizosphere propagules were different in soils under different vegetation covers. Roy-Bolduc et al. (2016) found a significant correlation between vegetation and fungal rhizosphere communities which were influenced by similar soil physicochemical properties. According to Setiawati (2014), the numbers of soil microbes found at plant rhizosphere were related to root exudate. Some researches showed that root exudate plays a central role in influencing interactions with neighboring plants and microbes. The quantity and quality of root exudate depend on plant species, developmental stage, and environmental factors. Garcia et al. (2015) reported a similar result. Meliani et al. (2012) stated that the activity and species composition of microbes were generally influenced by many factors including soil physicochemical properties, temperature, and vegetation.

The genera with a higher dominance in the total fungi isolated, according to the number of the genus, were Aspergillus (74\%), Penicillium (8\%), Gliocladium (4\%), Cephalosporium, Gliocladium, Humicola, Trichoderma, Paecilomyces, and unidentified genera (2\%). The results of this study showed that the reclamation areas were dominated by Aspergillus and Penicillium (Table 2). Kurakov et al. (2008) reported similar fungal genus in their work, and Garcia et al. (2015) stated that these genera are capable of using different substrates in the soil, they predominated over other fungal propagules that used only a few specific substrates. Domsch et al. (1980) stated that Aspergillus and Penicillium can utilize a wide range of substrate and can survive under extreme environmental conditions. Gomez et al. (2016) stated the reason why other fungal genera were in a low proportion or absent in the sampling areas was that saprophytic fungi present in a high relative density. After nine years of reclamation, the soil had higher fungal propagules showed lower fungal diversities than disturbed soil. The higher fungal propagules and lower fungal diversities are related to either adverse soils or surface conditions, or to soils high in nutrients levels. Frezquez et al. (1987) described that the composition of fungal rhizosphere is related to the properties of the soil, as well as to the type of vegetative cover during succession. Generally, a high diversity of fungal species and a few individual organisms per species are indication of stable and well-balanced soil ecosystems. On the contrary, low fungal diversity with high numbers of individual organisms per species indicate unstable or stressed soil ecosystems.

The results of this study indicated that six stages of reclamation significantly altered the physicochemical properties of post-coal mining sites (Figure 8). The soil pH after two years of reclamation was significantly higher than the undisturbed soil in any of the reclamation areas. Organic carbon concentrations after nine years of reclamation were significantly higher than the undisturbed 
soil and the later reclamation stages. The concentration of total $\mathrm{N}$, available $\mathrm{P}$, and available $\mathrm{K}$ generally increased as the year went up to the nine years after reclamation but decreased slightly in the later reclamation stages. The accumulation of many soil physicochemical properties was found to be higher in the nine years after reclamation compared to any of the reclamation areas. As described by Frezquez et al. (1987), these results suggest that the reclamation areas may not yet be stable since there may still adverse soil chemical and physical properties (i.e. high salts and high clay contents). Studies have shown significant interactions between soil and vegetation during a reclamation process, such that soil and vegetation are constantly evolving and developing (Frezquez et al., 1988; Meliani et al. 2012; Yang et al. 2016). Rousk et al. (2009) describe fungi and bacteria are the two groups that dominate the microbial decomposer community, and, crudely define that they share the function of decomposing organic matter in the soil, indicating that there is a strong potential for interaction. More recently, Garcia-Palacious et al. (2015) and Ashworth et al. (2017) reported that soil microbial communities are vital for continuous cycling of nutrient and for driving aboveground ecosystems. Vegetation cover and fungal rhizosphere propagules varied among six reclamation stages, leading to the differences in both mineralization of soil organic matter and soil physicochemical properties.

The fungal rhizosphere propagules correlated negatively with soil $\mathrm{pH}$ and organic carbon. The slightly higher fungal propagules in the reclamation areas can be attributed to lower soil $\mathrm{pH}$ and organic carbon concentrations. The relation of fungal propagules to soil $\mathrm{pH}$ demonstrated that fungal propagules increased as $\mathrm{pH}$ decreased. These results are in agreement with the previous reports by Rousk (2009) and Udom and Benwari (2018), focusing on the effects of fungal growth and biomass on soil $\mathrm{pH}$. In this study, soil chemical analysis shows that the soil $\mathrm{pH}$ ranged between 6.27 to 8.47 , generally, fungal growth was optimal at $\mathrm{pH} 4.5$ to 5 , and then decreased above pH 5 (Suciatmih 2006; Setiawati 2014). Our results also indicate that higher fungal propagules can be attributed to lower organic carbon concentrations. Hrselova et al. (1999) reported the similar results in their work, the concentration of CFU of culturable fungi were negatively correlated with organic carbon observed in field-collected soil samples.

On the other hand, the increase of fungal propagules of the soil was positively correlated to the increase of total $\mathrm{N}$, available $\mathrm{P}$, and available $\mathrm{K}$ indicating that total $\mathrm{N}$, available $P$, and available $K$ increased as the fungal propagules with a range of about $3.7 \times 104$ to $1.2 \times 105 \mathrm{CFU}$ $\mathrm{g}^{-1}$ soil. As described by White et al. (1997), fungi can withstand a much wider $\mathrm{pH}$ range, and many can produce organic acids which can solubilize and boosts the availability of $\mathrm{N}, \mathrm{P}, \mathrm{K}$ and $\mathrm{Fe}$ in the soil. A lot of fungi are capable of producing organic acids, including Aspergillus niger (citric, oxalic, gluconic), Aspergillus spp. (citric, malic, tartaric, a-ketoglutaric, itaconic, aconitic), and Penicillium spp. (citric, tartaric, a-ketoglutaric, malic, gluconic). By altering parameters such as the $\mathrm{N}, \mathrm{P}$ and $\mathrm{K}$ balance of the soil and optimum $\mathrm{pH}$, these species can be used to produce a wide range of organic acid for the mobilization of nutrients and facilitate their plant uptake from the rhizosphere.

The presence of fungal rhizosphere is an important agent to improve the availability of total nitrogen. As discussed above, fungi indirectly affect $\mathrm{N}$ fixation through bacteria present in mycelia. During this process, fungi translocate carbon and $\mathrm{P}$ from the plant roots to the associated bacteria for $\mathrm{N}$ fixation (Rashid et al. 2016). Setiawati (2014) stated that some fungal rhizospheres are capable to dissolve soil $\mathrm{P}$ continuously. Their activity increases $\mathrm{P}$ availability through several mechanisms, i.e., mineralization of organic $\mathrm{P}$ by phosphatase enzyme to an organic $\mathrm{P}$, which can be used by the plants, competition of adsorption site, and changes of soil reaction. Rashid et al. (2016) described the major processes involved in mobilizing $\mathrm{K}$ are acidolysis and complex lysis exchange reactions. During acidolysis, soil microbe such as fungi decreases the local $\mathrm{pH}$ by producing succinic, citric, gluconic, a-keto-gluconic and oxalic acids. This process plays an important role in mobilizing or solubilizing insoluble form and structural unavailable forms of $\mathrm{K}$ compounds into soil solution resulting in an increased $\mathrm{K}$ availability in the rhizosphere.

In conclusion, the present study results show that nine isolates of microfungi were identified from the six stages of reclamation samples in post-coal mining reclamation sites, i.e., Aspergillus, Penicillium, Cephalosporium, Gliocladium, Humicola, Trichoderma, Paecilomyces while two other genera are unidentified yet. The genera with a higher dominance in the total fungi isolated, according to the number of the genus, were Aspergillus (74\%), Penicillium (8\%), Gliocladium (4\%), Cephalosporium, Gliocladium, Humicola, Trichoderma, Paecilomyces, and unidentified genera $(2 \%)$. Numbers of fungal propagules were not significantly different in the undisturbed soil, the disturbed soil or the reclaimed soil. Fungal propagules increased in the early year after reclamation and then decreased after twelve years of reclamation comparable to those of the undisturbed soil. The fungal rhizosphere propagules were different in soils under different vegetation covers. Fungal populations and community composition were related to soil properties and site age of reclamation. The fungal propagules were negatively correlated with soil $\mathrm{pH}$ and organic carbon. On the contrary, fungal propagules to be positively correlated with total $\mathrm{N}$, available $\mathrm{P}$, and available $\mathrm{K}$.

\section{ACKNOWLEDGEMENTS}

The authors would like to thank Coordinator of Graduate School of Environmental Sciences, Mulawarman University Samarinda, Indonesia who has assisted in field study facilities and Muji, the laboratory analyst for the Soil Forest Rehabilitation Study Center, Mulawarman University, Samarinda. 


\section{REFERENCES}

Ashworth AJ, DeBruyn JM, Allen FL, Radosevich M, Owens PR. 2017 Microbial community structure is affected by cropping sequences and poultry litter under long-term no-tillage. Soil Biol Biochem 114: 210219.

Barnett HL, Hunter BB. 1972. Illustrated Genera of Imperfect Fungi. 3rd ed. Burgess Publishing Co., Minneapolis.

Birch P, Bentham H.,, .Harris J.A .1991.Soil Microbial Ecosystems: Importance for The Effective Restoration of Mined Lands. Proceedings America Society of Mining and Reclamation 1991: 631640. DOI: $10.21000 / J A S M R 91020631$

Domsch KH, Gams W, Anderson T. 1980. Compendium of Soil Fungi. Academic Press, London.

Frac M, Hannula SE, Bełka M, Dryczka JM.2018. Fungal biodiversity and their role in soil health. Front Microbiol 9: 707. DOI 10.3389/fmicb.2018.00707

Fresquez PR, Aldon EF, Lindemann WC.1987. Diversity and composition of soil fungi associated with reclaimed coal mine spoils and soils. Proceed. Am. Soc. Min. Recl. pp 107-114.

Frezquez PR, Sabey BR, Klein DA.1988. Soil fungal community-plant rhizosphere interactions during the early stages of ecosystem development on reclaimed coal mine soils. Proceedings of The American Society for Surface Mining and Reclamation, The Bureau of Mines, and The Office of Surface Mining Reclamation and Enforcement. Pittsburgh, Pennsylvania, April 19-21, 1988.

Garcia WM, Zago BW, da Silva Nunes JS, de Carvalho IF.2015. Diversity of filamentous fungi in Cerrado soil under native vegetation. Revista Brasileira de Biociencias. 13 (4): 245-249.

Garcia-Palacious P, Prieto I, Ourcival JM, Hattenschwiler S. 2015 Disentangling the litter quality and soil microbial contribution to leaf and fine root litter decomposition responses to reduced rainfall Ecosystems. DOI: 10.1007/s10021-015-9946-x.

Gomez RP, Auliciano MB, Monaco CI, Kripelz N,Cordo CA. 2016 Composition and dynamics of the fungal populations in a typical Phaeozem luvico in Argentina. Cogent Food Agric 2: 11-25.

Hrselova H, Chvatalova I, Vosatka M and Klir J . 1999. Correlation of abundance of arbuscular mycorrhizal fungi, bacteria and saprophytic microfungi with soil carbon, nitrogen and phosphorus. Folia Microbiologica. 44 (6): 683-687.

Kurakov AV, Lavrent'ev RB, Nechitailo TY, Golyshin PN, Zvyagintsev DG 2008. Diversity of facultatively anaerobic microscopic mycelia fungi in soils. Microbiology. 77 (1): 90-98.

Li Y, Wen H, Chen L, Yin T. 2014. Succession of bacterial community structure and diversity in soil along a chronosequence of reclamation and revegetation on coal mine spoils in China. PLoS ONE 9 (12): e115024. DOI: 10.1371/journal.pone.0115024.

Li J, Liu F, Chen J (2016) The Effects of Various Land Reclamation Scenarios on the Succession of Soil Bacteria, Archaea, and Fungi
Over the Short and Long Term. Front. Ecol. Evol. 4:32. DOI: 10.3389/fevo.2016.00032

Meliani A, Bensoltane A, Mederbel K. 2012. Microbial diversity and abundance in soil: related to plant soil type. Am. J. Plant Nutr. Fert. Technol. 2 (1): 10-18.

Mummey DL, Stahl PD, Buyer JS. 2002. Soil microbiological properties 20 years after surface mine reclamation: spatial analysis of reclaimed and undisturbed areas. 34: 1717-1725.

Noviyanto A, Purwanto, Minardi S, Supriyadi. 2017. The assessment of soil quality of various age of land reclamation after coal mining: a chronosequence study. J. Degrade. Min. Land Manage. 5 (1): 10091018 .

Rana S, Stahl PD, Ingram LJ, Wick AF. 2007. Soil microbial community composition in reclaimed soil under different vegetation in Wyoming mine lands. Proceed. Am. Soc. Min. Reclamation 2007. Lexington.

Rashid MI, Mujawar LH, Shahzad T, Almeelbi T, Ismail IMI, Oves M. 2016. Bacteria and fungi can contribute to nutrients bioavailability and aggregate formation in degraded soils. Microbiol Res. 183: 26-41.

Rousk J, Brookes PC, Baath E. 2009. Contrasting soil pH effects on fungal and bacterial growth suggest functional redundancy in carbon mineralization. Appl. Environ. Microb. 75 (6): 1589-1596.

Roy-Bolduc A, Laliberte E, Boudreau S, Hijri M. Strong linkage between plant and soil fungal communities along successional coastal dune system. FEMS Microbiol. Ecol. 92 (10): 1-10.

Setiawati TC. 2014. Correlations between soil microbe and soil chemical properties in limestone mining area: case study at Southern Jember Indonesia. Int. Con. Chemical, Environment \& Biological Sciences. September 17-18th 2014 Kuala Lumpur. Malaysia.

Suciatmih. 2006. Soil mycoflora of banana and cassava in peatland and alluvial soil in Bengkulu. Biodiversitas. 7 (4): 303-306. [Indonesian].

Turnbull LA, Isbell F, Purves DW, Loreau M, Hector A. 2016. Understanding the value of plant diversity for ecosystem functioning through niche theory. Proc. R. Soc. B 283: 20160536

Udom BE, Benwari O. 2018. Bacteria to fungi and organic carbon in notill ultisols after applications of corn residues and poultry manure. Int. J. Plant Soil Science. 22 (3): 1-8.

White C, Sayer JA, Gadd.GM. 1997. Microbial solubilization and immobilization of toxic metals: key biogeochemical processes for treatment of contamination. FEMS Microbiol. Rev. 20: 503-516.

Widyati .E 2013. Pentingnya keragaman fungsional organisme tanah terhadap produktivitas lahan. Tekno Hutan Tanaman 6 (1): 29 - 37. [Indonesian]

Yang H, Zhang H, Chen Y, Xu T, Cheng Z, Liang J. 2016. Assessment of reclamation treatments of abandoned farmland in an arid region of China. Sustainability 8 (11): 1183. DOI: $10.3390 /$ su8111183.

Yusuf M dan Arisoesilaningsih E. 2017. Exotic plant species attack revegetation plants in post-coal mining areas. 8th Intl. Conf. on Global Resource Conservation. AIP Conf Proc 1908 (1): 040002. DOI: $10.1063 / 1.5012716$ 